\title{
Gender and Hand Dominance as Predictors of Forearm Disuse Osteoporosis in Patients with Traumatic Upper Extremity Injury
}

\author{
Üst Ekstremite Travmatik Yaralanmalı Hastalarda Önkol Kullanmama \\ Osteoporoz Prediktörleri Olarak Ginsiyet ve El Dominansı
}

\author{
ilhan Karacan¹, şafak Sahir Karamehmetoğlu², Mustafa Akif Sarıyıldız', Aynur Özen³ \\ 1 Department of Physical Medicine and Rehabilitation, Vakif Gureba Training and Research Hospital, istanbul, Turkey \\ 2 Department of Physical Medicine and Rehabilitation, Cerrahpasa Medical Faculty, Istanbul University, istanbul, Turkey \\ 3 Department of Nuclear Medicine, Vakıf Gureba Training and Research Hospital, istanbul, Turkey
}

\section{Abstract}

Objective: Immobilization of an injured extremity leads to a rapid loss of bone. It is somewhat unclear why one traumatic insult should give rise to bone loss in one patient, while the identical insult in another patient does not. The aim of this study was to investigate whether there were other risk factors for disuse osteoporosis, in addition to immobilization.

Materials and Methods: Ninety patients who had suffered a mechanical traumatic injury isolated to their upper extremity were included in this study. Effects of age, gender, types of injury, affected extremity (dominant or non-dominant), immobilization period, and remobilization period on the distal radius bone mineral density (BMD) of the injured side were investigated. BMD was measured using dual energy $X$-ray absorptiometry.

Results: A low BMD (LBMD) was found in $31.1 \%$ of patients. The mean age was not significantly different between the normal BMD and LBMD groups. The female/male ratio was significantly higher in the LBMD group. The affected extremity was on the non-dominant side in $29.0 \%$ of the normal BMD group and in $53.5 \%$ of the LBMD group $(p=0.045)$. The mean immobilization period was significantly higher in the LBMD group. There were no significant differences in the remobilization period between the LBMD and normal group. It was found that LBMD was only associated with female gender, non-dominant side injury and the immobilization period.

Conclusion: Considering that non-dominant side injury, female gender and length of the immobilization may be important for development of disuse osteoporosis, we conclude that the prevention measures should be focused mainly on patients with these risk factors in order to reduce the risk of disuse osteoporosis. (Turk J Rheumatol 2010; 25: 137-40)

Key words: Disuse osteoporosis, risk factor, gender, non-dominant side

Received: 31.10 .2008

Accepted: 04.02.2009

\section{Özet}

Amac:: Yaralanan ekstremitenin immobilizasyonu hızlı kemik kaybına neden olmaktadır. Benzer travmatik yaralanma geçiren hastalardan bir kısmında kemik kaybı gelișmezken, diğer bir kısmında gelișmesi tam olarak açıklanamamıștır. Bu çalıșmanın amacı kullanmama osteoporozunun, immobilizasyona ilaveten bașka risk faktörleri olup olmadığını araștırmaktı.

Yöntem ve Gereçler: Üst ekstremitede mekanik yaralanma geçiren 90 hasta çalıșmaya dahil edildi. Yașın, cinsiyetin, yaralanan doku tipinin, yaralanan ekstremitenin (dominant-nondominant), immobilizasyon süresinin ve remobilizasyon süresinin yaralanan ekstremite kemik mineral yoğunluğu (KMY) üzerine etkisi incelendi. KMY ölçümleri dual enerji X ışını absorpsiyometrisi ile yapıldı.

Bulgular: Düșük KMY olguların \%31.1'inde saptandı. Düșük ve Normal KMY olan grupların yas ortalamaları istatistiksel olarak farklı değildi. Kadın/Erkek oranı düșük KMY grubunda anlamlı olarak daha yüksek idi. Yaralanan ekstremite, normal KMY grubundaki olguların \%29.0 unda, düșük KMY grubundaki olguların $\% 53.5^{\prime}$ inde non-dominant ekstremite idi $(p=0.045)$. Ortalama immobilizasyon süresi düșük KMY grubunda anlamlı olarak daha uzun idi. Remobilizasyon süresi açısından gruplar arasında fark yoktu. Düșük KMY ile kadın cinsiyet, non-dominant taraf yaralanması ve immobilizasyon süresi ilișkili bulundu.

Sonuç: Kullanmama osteoporozu gelișiminde immobilizasyon süresine ilaveten non-dominant taraf yaralanmanın ve kadın cinsiyetin önemli olabileceği dikkate alınırsa, kullanmama osteoporozu riskini azaltmak için koruyucu önlemlerin bu risk faktörlerini tașıyan hastalara odaklanması yararlı olabilir.

(Turk J Rheumatol 2010; 25: 137-40)

Anahtar sözcükler: Kullanmama osteoporozu, risk faktörü, cinsiyet, non-dominant taraf

Alındığı Tarih: 31.10.2008 Kabul Tarihi: 04.02.2009 


\section{Introduction}

Reduction of mechanical stress on bone inhibits bone formation and accelerates bone resorption and leads to what has been called disuse osteoporosis. This bone loss can be localized or generalized. Prolonged therapeutic bed rest, immobilization due to motor paralysis from injury to the central nervous system or peripheral nerves and the application of cast to treat fractures are the common causes of disuse osteoporosis (1).

Traumatic upper extremity injuries are common clinical problems (2). Injury with subsequent immobilization and disuse of the injured extremity lead to a rapid loss of bone. However, the role of immobilization in the development of post-traumatic osteoporosis is somewhat unclear. On the basis of current knowledge, it seems that immobilization-inducement changes in bone vary depending on factors such as the severity of the injury and the type and duration of the immobilization $(3,4)$. The aim of this study was to investigate whether there were other risk factors for disuse osteoporosis, in addition to immobilization.

\section{Materials and Methods}

\section{Subjects}

Ninety patients (16 females and 74 males) who had suffered a unilateral mechanical traumatic injury isolated to their upper extremity were included in this study. Twenty-three patients had digital, median or ulnar nerve injury, 83 patients had flexor tendon injury and six patients had phalanx fracture. All patients underwent a general physical and neurological examination and were questioned about their medical history. Patients with chemical or heat injury of the upper extremity, history of immobilization of the upper extremity (peripheral nerve entrapment, tendinitis, etc.), postmenopausal osteoporosis, and secondary osteoporosis risk factors (early menopause, amenorrhea, inflammatory joint disease [rheumatoid arthritis, etc.], chronic diarrhea, surgery [ovariectomy, thyroidectomy, orchiectomy], use of drugs that are known to affect bone metabolism (corticosteroid, heparin) and endocrine/metabolic disease) were excluded.

The mean age was $33.4 \pm 7.8(20-50)$ years. Eighty-five patients $(94.4 \%)$ were right-handed. The affected distal upper extremity was dominant in $57(63.3 \%)$ patients.

All patients with tendon and/or nerve injuries were operated. The fractured phalanx was managed by closed reduction. The operated or reducted region was immobilized within a plaster cast (immobilization period). Duration of the immobilization varied from 3 to 6 weeks. Effects of age, gender, types of injury (tendon injury, nerve injury, fracture), affected extremity (dominant or non-dominant), immobilization period, and remobilization period (interval between removal of the splint and measurement of the distal radius bone mineral density $[B M D]$ ) on the distal radius BMD of the injured side were investigated.

\section{Measurement of the Distal Radius BMD}

Bone mineral density was measured in the injured forearm (ultra-distal radius and total radius) using dual energy X-ray absorptiometry (GE-LUNAR DPX PRO, Lunar Corporation, Madison, WI, USA). Coefficient of variation was $1.41 \%$ for the radius. If the patients had a $T$ score below -1 in at least one of the radial regions in which BMD was measured, they were considered to have low BMD. The BMD measurement was carried out after removing the plaster cast splints. The time interval between the traumatic injury and the BMD measurement varied from 3 to 12 weeks.

\section{Statistical Analysis}

Continuous variables were summarized as mean \pm standard deviation. The Mann-Whitney $U$ test was used to analyze statistically significant differences in age, immobilization period and remobilization period between normal BMD and low BMD groups. The Continuity Correction chi-square test or Fisher's Exact test were used for categorical data. Next, a multivariate analysis was performed to detect independent predictors for the occurrence of low BMD by using a binary logistic regression analysis and to find confounding effects between potentially independent predictors. A forward stepwise method was used to construct multivariate logistic regression models in relation to various dependent variables, with the inclusion criterion of a $P$ value less than 0.05 and exclusion criterion of a $P$ value greater than 0.1 . To determine whether the regression model adequately described the data, the Hosmer-Lemeshow goodness-of-fit test was used. If the significance value is less than 0.05, the Hosmer-Lemeshow statistic indicates a poor fit (5). Ninety-five percent confidence interval $(95 \% \mathrm{Cl})$ was used to evaluate significance of the odds ratio. Wald test was used to evaluate significance of individual B coefficients. A $P$ value less than 0.05 was considered statistically significant. SPSS version 10.0 for Windows was used as the data management software package.

\section{Results}

Low BMD was determine in $18.9 \%$ of cases in the ultra-distal radius and in $21.1 \%$ of cases in the total radius. Low BMD was found in $28(31.1 \%)$ patients in at least one of these two regions.

The mean age was not significantly different between the two groups. The female/male ratio was significantly higher in the low BMD group (Table 1).

The affected extremity was on the non-dominant side in $29.0 \%$ of the normal BMD group, and in $53.5 \%$ of the 
low BMD group $(p=0.045)$. The mean immobilization period was significantly higher in the low BMD group. There were no significant differences in the remobilization period between low BMD and normal groups (Table 2).

A multivariate logistic regression model showed that low BMD was associated with gender, side of injured extremity and immobilization period (Hosmer-Lemeshow test, $\mathrm{p}=0.990$ ) (Table 3).

\section{Discussion}

Bone mass is not only subject to systemic hormonal homeostatic mechanisms, but also to local mechanical influences. Injury with subsequent immobilization and disuse can lead directly to a local reduction in bone mass (4). In this study, we sought to determine why a traumatic insult in one patient should give rise to a bone loss while the identical insult in another patient did not. We thus investigated risk factors for localized disuse osteoporosis, other than immobilization, in patients with traumatic distal upper extremity injury. We found that non-

Table 1. Demographic features in the two groups

\begin{tabular}{lccc}
\hline & $\begin{array}{c}\text { Normal BMD } \\
(\mathbf{n}=\mathbf{6 2})\end{array}$ & $\begin{array}{c}\text { Low BMD } \\
(\mathbf{n}=\mathbf{2 8})\end{array}$ & $\mathbf{P}$ \\
\hline Age (years) & $34.2 \pm 8.0$ & $31.6 \pm 7.2$ & 0.173 \\
Gender (female / male) & $7 / 55$ & $9 / 19$ & 0.036 \\
Right-handedness (\%) & 93.5 & 96.4 & 1.000 \\
\hline BMD: Bone Mineral Density & & & \\
\hline
\end{tabular}

Table 2. Injury-related variables in the two groups

\begin{tabular}{lccc}
\hline & $\begin{array}{c}\text { Normal BMD } \\
(\mathbf{n = 6 2 )}\end{array}$ & $\begin{array}{c}\text { Low BMD } \\
(\mathbf{n}=\mathbf{2 8})\end{array}$ & $\mathbf{P}$ \\
\hline Phalanx fracture (\%) & 6.5 & 7.1 & 1.000 \\
Nerve injury (\%) & 22.5 & 32.1 & 0.483 \\
$\begin{array}{l}\text { Tendon injury (\%) } \\
\begin{array}{l}\text { Affected extremity } \\
\text { (right/left) }\end{array}\end{array}$ & 91.9 & 92.8 & 1.000 \\
$\begin{array}{l}\text { Affected extremity } \\
\text { (non-dominant/ }\end{array}$ & $18 / 44$ & $14 / 14$ & 0.285 \\
dominant) & & $15 / 13$ & 0.045 \\
$\begin{array}{l}\text { Immobilization } \\
\text { duration (weeks) }\end{array}$ & $4.2 \pm 1.0$ & $5.0 \pm 0.9$ & 0.001 \\
$\begin{array}{l}\text { Remobilization } \\
\text { duration (weeks) }\end{array}$ & $2.0 \pm 2.3$ & $2.0 \pm 2.0$ & 0.707 \\
\hline
\end{tabular}

dominant extremity injury and female gender in addition to length of immobilization were important risk factors for low BMD.

Osteoporosis is a more common problem in females than males (6). Painful posttraumatic osteoporosis, the previous term for complex regional pain syndrome, is also more common in females (7). In this study, risk factors for low BMD in the distal aspect of the radius were found to be more pronounced in female than in male patients. This may be attributed to the lower peak bone mass in female patients. The lower peak bone mass and the lower bone reserve can facilitate development of osteoporosis during immobilization.

Kekilli et al. (8) showed that BMD measurements were reduced significantly more over time in the middiaphysis and distal regions of the ulna and in the ultradistal region of the radius in patients operated on for non-dominant forearm clean-cut injuries, whereas BMD of the radius and ulna did not change significantly with time in patients operated on for dominant forearm clean-cut injuries. Our study showed that the risk of low BMD in the distal radius was 3.35 times higher in patients with non-dominant side upper extremity injuries than in patients with dominant side upper extremity injuries. This may be attributed to the lower bone mass of the non-dominant side radius. Maclntyre et al. (9) reported that the dominant limb had a greater bone mass and greater total bone volumetric density in the radius. In this study, BMD was measured only in the injured forearm. We do not have any knowledge about both dominant and non-dominant side radius BMD values before the injury. Obtaining this knowledge in a human study is not possible; therefore, it is a limitation of this study.

In conclusion, the current study showed that female gender and non-dominant side injury in addition to a longer immobilization period increased the risk for low BMD in the distal radius of the injured side in patients with traumatic distal upper extremity injury. It may be suggested that the prevention measures should be focused mainly on the patients with these risk factors in order to reduce the risk of localized disuse osteoporosis.

\section{Conflict of Interest}

No conflict of interest is declared by authors.

Table 3. B coefficients and odds ratios of variables in the final regression model

\begin{tabular}{lcccccccc}
\hline & B & SE & Wald & df & P value & OR & \multicolumn{2}{c}{$\begin{array}{c}95 \% \text { Cl for OR } \\
\text { Lower }\end{array}$} \\
\hline Female gender & 1.312 & 0.630 & 4.341 & 1 & 0.037 & 3.714 & 1.081 & 12.762 \\
Non-dominant side injury & 1.209 & 0.534 & 5.135 & 1 & 0.023 & 3.351 & 1.177 & 9.538 \\
Immobilization duration & 0.823 & 0.259 & 10.091 & 1 & 0.001 & 2.278 & 1.371 & 3.787 \\
Constant & -5.350 & 1.341 & 15.923 & 1 & 0.000 & 0.005 & & \\
\hline
\end{tabular}

B: Coefficients, SE: Standard error, df: Degree of freedom, OR: Odds ratio, Cl: Confidence interval 


\section{References}

1. Takata S, Yasui N. Disuse osteoporosis. J Med Invest 2001; 48: 147-56.

2. Dias JJ, Garcia-Elias M. Hand injury costs. Injury 2006; 37: 1071-7.

3. Whedon GD. Disuse osteoporosis: physiological aspects. Calcif Tissue Int 1984; 36 Suppl 1: 146-50.

4. Jarvinen M, Kannus P. Injury of an extremity as a risk factor for the development of osteoporosis. J Bone Joint Surg Am 1997; 79: 263-76.

5. Freund RJ, Wilson WJ, Sa P. Regression Analysis Statistical Modeling of a Response Variable. 2nd ed. New York: Elsevier, 2006.
6. Holroyd C, Cooper C, Dennison E. Epidemiology of osteoporosis. Best Pract Res Clin Endocrinol Metab 2008; 22: 671-85.

7. McBride A, Atkins R. Complex regional pain syndrome. Curr Orthopaedics 2005; 19: 155-65.

8. Kekilli E, Ertem K, Yologlu S, Ceylan F. Comparisons of the bone mineral density in dominant and nondominant forearm following clean-cut tendon injuries, repair, and passive mobilization. J Clin Densitom 2006; 9: 198-201.

9. MacIntyre NJ, Adachi JD, Webber CE. In vivo detection of structural differences between dominant and nondominant radii using peripheral quantitative computed tomography. J Clin Densitom 1999; 2: 413-22. 